\title{
POPULATION DYNAMICS OF TOMATO PIN WORM, TUTA ABSOLUTA MEYRICK (LEPIDOPTERA: GELECHIIDAE) AND SURVEY OF ASSOCIATED NATURAL ENEMIES ON TOMATO IN FAYOUM GOVERNORATE
}

Abd-El-Gayed, A. A., Abdella, M. M. H. and Salwa S. B. Desoki Plant Protection Department, Faculty of Agriculture, Fayoum University

\section{ABSTRACT}

The present work was carried out at Experimental Farm, Fac. of Agric., Fayoum Univ. and aimed to shad some a light on population fluctuations of the tomato pinworm, T. absoluta and its associated natural enemies and relation to some weather factors at Fayoum Governorate on tomato crop (Solanum lycopersicum L.) cultivated in four successive plantations during 2011/12 and 2012/13 seasons.Natural enemies associated with $T$. absoluta were the predator (Atheta sp.) and 3 parasitiod hymenopteran insect species (Bracon sp, Halticoptera sp and Apanteles sp). The entomopatogenous bacteria Bacillus sp (Bacillales: Bacillaceae) was also isolated from dead and moribund larvae.

In summer plantations, no larvae were observed on leaves and fruits during all season 2011. However, during the second summer season of 2012, slight infestations were recorded on tomato leaves during the farmer 4 weeks of the season and no infestations were observed on the fruits.

In winter plantation: in 2011/12 the population fluctuated slightly from Nov. 2011until end of Feb 2012, one period activity was recorded from end of Feb until end of April. Fruits infestations began to appear from end of April extended to end of plantation. While in 2012/13, few larvae began to appear at mid Nov 2012, increased gradually during the successive weeks to arrive its highest on leaves at end of Feb 2013 (peak of 681 larvae /20 leaves). Fruit infestation increased slightly during the successive weeks of fruiting to arrive the highest count of larvae during the first week of March 2013 (214 larvae /20 fruits).

Key words: Tuta absoluta, population dynamics, natural enemies, tomato INTRODUCTION

Tuta absoluta Meyrick (Lepidoptera: Gelechiidae) is well known as a serious pest of tomato crops in Europe and South America Probst et al. (1999). T. absoluta is native to South America and detected in Europe for the first time in Spain at the end of 2006. Since then, it has rapidly invaded other European countries and spread throughout the Mediterranean basin, including parts of

Fayoum J. Agric. Res. \& Dev., Vol. 28, No.1, January, 2014 
Abd - El-Gayed, A. A., et al.,

North Africa and the Middle East where it immediately reached damaging levels (Alberto et al., 2012).

In Egypt, T. absoluta noticed for the first time on July 2009 at Nubaria, El-Behera Governorate and invaded in the nearest Governorate to Libya (Marsa Mtrooh) in 2009. By 2010 it reached Giza, and started to be established in all Governorates of Egypt and reached the borders and north part of Sudan on June 2011(Bekheit and Impiglia, 2010). Tomato is cultivated in Egypt in all year round overlapping plantations, additional to the moderate climate in most of the year, allowing this pest to access its preferred host and favoring its rapid spread (Sobhy, 2011).T.absoluta also attacks other crop plants of Solanaceae including potato, eggplant, pepino and tobacco. It was also recorded on many solanaceous weeds such as, Datura stramonium, Lycium chilense, and Solanum nigrum. The pest feeds on leaves, flowers, stems and especially fruits at any developmental stage, from seedlings to mature plants. In the absence of control strategies, fruit damage can reach $100 \%$. The damage leaves is caused when larvae feed on the mesophyll, expanding miners, affecting photosynthetic capacity, thus reduces the yield (Alberto et al., 2012).

In favorable weather conditions, eight to ten generations occur per year. Climatic comparisons are useful tool for evaluating where the species might become established within a new geographical region (Mack et al., 2002).

Therefore, the present study aimed to focus on the following criteria:

1-Survey and population dynamics of $T$. absoluta and associated natural enemies on tomato as related to weather conditions in Fayoum Governorate.

2-Isolation of the pathogenic organisms found on dead and moribund $T$. absoluta larvae.

\section{MATERIALS AND METHODS}

1- Survey of T. absoluta:

Quantitative and qualitative survey of $T$. absoluta and associated natural enemies were carried out in Fayoum Research Farm at Fayoum Governorate, for four successive plantations for two successive years (from June 2011 to March 2013), an area (1/4 feddan) for each plantation. The variety Super Jakal was used in the summer plantation (from June to October 2011 and June to September 2012) and the variety 765 Hybrid was used in the winter plantation (from November 2011 to May 2012 and from September 2012 to March 2013).

After 10-15 from of transplantation, the tomato pin worm was collected weekly and randomly (20 compound leaves and 20 fruits per sample). Samples were picked up gently, placed in paper bags and transferred to laboratory for counting larvae by using binocular sterio microscope.

Fayoum J. Agric. Res. \& Dev., Vol. 28, No.1, January, 2014 


\section{Population fluctuation:}

Weekly counted larvae in larvae/20 compound leaves and fruits were used for studying the population fluctuation of the pest in relation to some weather factors (average temperatures and relative humidity).

Weather factors data were obtained from the meteorological Station at Fayoum Governorate.

3. Collection and identification of associated natural enemies.

The collected predators and the parasitoids found associated with dead larvae of $T$. absoluta were preserved in alcohol $70 \% \& 5 \%$ glycerin in sample bottles. Samples were identified to species level by Profs. Dr. Ahmed Raouf, Hazem Abd El- Raouf and Mohamed. K. El- Akad (Plant Protec. Inst., Agric. Res. Center, Cairo).

Associated pathogenic bacteria were also isolated from dead and moribund larvae and identified by the specialists at microbiology Dept., Fac. Agri., Fayoum University.

\section{Statistical analyses:}

Correlation between the population of the pest and weekly means of the weather factors (average temperature and R.H \%) was evaluated by using simple correlation (r), the stepwise regression (R) and SPSS software program. (Senedecor and Cochran, 1967).

\section{Isolation of the entomopathogenic bacteria:}

Isolation of the associated pathogenic bacteria was carried out as follows.

The specimens were sterilized externally by passing them through the following solutions: Ethanol $70 \%$ for 1-2 minutes and then rinsed briefly in sterile distilled water. Such specimens were placed on L.B medium (10 gm $\mathrm{Nacl}_{2}$, 5gm yeast extract, 10 Treptone, $15 \mathrm{gm}$ agar agar and $1000 \mathrm{ml}$ distilled water) in sterilized Petri dishes incubated at $30^{\circ} \mathrm{C}$ for $48 \mathrm{hrs}$. The inoculum of each bacterial colony was used for purification and thereafter, their pathogenicity was evaluated by using Koch's postulates. The promised pathogenic bacteria were conserved in refrigerator at $5^{\circ} \mathrm{C}$ on solid L.B in sterilized Petri dishes and test tubes (slants) to be used in successive experiments.

\section{RESULTS AND DISCUSSION}

\section{Qualitative survey:}

Natural enemies associated with T. absoluta were identified, classified as 4 species, 4 genera, belong to 3 families and 2 orders, i.e. one predaceous insect from Order Coleoptera (Atheta sp), 3 parasitiod species from Order Hymenoptera (Bracon sp, Halticoptera sp and Apanteles sp) and the entomopatogenous bacteria Bacillus sp (Bacillales: Bacillaceae). In this respect (in Brazil), Melo and Campos (2000) surveyed the natural enemies associated with T. absoluta. They recorded that the hymenopterans

Fayoum J. Agric. Res. \& Dev., Vol. 28, No.1, January, 2014 
Abd - El-Gayed, A. A., et al.,

parasitoid, Bracon sp emerged from larvae. Marchiori et al. (2004) reported three groups of parasitoids were collected from T. absoluta on tomato plants; 21 specimens of Bracon sp., one specimen of Earinus sp. and 13 specimens of Conura sp. Moacyr et al (2005) observed that the predators were more abundant than parasitoids. The most abundant predators were Cycloneda sanguinea L. (Coleoptera: Coccinellidae) and Staphylinid adults (Coleoptera). Lucia et al (2012) in Southern Italy recorded 13 genera of 6 families (Ichneumonidae, Braconidae, Eulophidae, Elasmidae, Pteromalidae and Trichogrammatidae) associated with $T$. absoluta. In particular, of the 10 identified species, Diadegma pulchripes (Kokujev), Bracon osculator (Nees), B.(Habrobracon) nigricans Szepligeti, Necremnus tidius (Walker), N. artynes (Walker), Neochrysocharis formosa (Westwood), Pnigalio soemius. (Walker), P. cristatus (Ratzeburg), P. incompletus (Boucek) and Halticoptera aenea (Walker). Also, Massimo et al. (2012) in Brazil recorded also13 genera and 6 families (Ichneumonidae, Braconidae, Eulophidae, Elasmidae, Pteromalidae and Trichogrammatidae) emerged from $T$. absoluta. Three species of Braconidae (Bracon hebetor (Say), B. osculator (Nees), B. nigricans Szepligeti) were among the 16 identified prasitiod species.

\section{Quantitive survey:}

Total weekly counts of $T$. absoluta larvae in leaves and fruits on tomato plants were used for studying the relationship between such population and some weather factors (average temperatures and R.H \%) during two successive years $(2011 / 12 \& 2012 / 13)$.

\subsection{Summer plantation (Super Jakal)}

Weekly collected samples of tomato leaves and fruits from the summer plantation of 201 lindcated completely absence of infestation, where no larvae were observed on all of the collected samples during all season. However, during the second summer plantation of 2012, which extended from Mid June until end of August (11weeks), slight infestations were recorded on tomato leaves during the $4^{\text {th }}$ week of the season (from Mid June until Mid July). Recorded infestations during this period ranged from 33-158 larvae/20 compound leaves. No infestations were observed on the fruits throughout the season. Therefore, data recorded from winter plantations 2011/12 and 2012/13 were used for studying the relationships between some weather factors (mean of temp. and R.H. \%) and T. absoluta population (weekly number count of larvae/20 compound leaves and 20 fruits).

In this respect, Saad et al. (2013) in Egypt stated that T. absoluta, causes severe damage to the foliage and fruit on tomato plants in 12 governorates during the flowering stage in summer plantation in 2010 and 2011. The survey showed that the degrees of infestation were 21,48 and $28 \%$ in Behara, Dommiett and Aswan Governorates, respectively. Corresponding

Fayoum J. Agric. Res. \& Dev., Vol. 28, No.1, January, 2014 
POPULATION DYNAMICS OF TOMATO PIN WORM

152

values in 2011 were $50 \%$ in Beni-suef Governorate and reached to $100 \%$ in ElGharbia, El-Monifia ‘El-Dakahleia, Dommiett, El-Qalubia, El-Sharkia and ElIsamlia Governorates.

Table(1):Simple correlation (r) and stepwise regression $(R \& b)$ for the relation between average Temp \& R.H. \% and population of $T$. absoluta.

\begin{tabular}{|c|c|c|c|c|c|}
\hline Plantation & Miners & $\begin{array}{l}\text { Weather } \\
\text { Factors }\end{array}$ & $\mathbf{r}$ & $\mathbf{R}$ & b \\
\hline \multirow{4}{*}{$\begin{array}{l}\mathbf{1}^{\text {st }} \text { plantation (Super } \\
\text { Jakal) } \\
\text { (Summer plantation) }\end{array}$} & \multirow{2}{*}{ Leaves } & Temp average & - & - & \\
\hline & & R.H. $\%_{\text {average }}$ & - & - & \\
\hline & \multirow{2}{*}{ Fruits } & Temp average & - & - & \\
\hline & & R.H. $\%_{\text {average }}$ & & & \\
\hline \multirow{4}{*}{$\begin{array}{c}2^{\text {nd }} \begin{array}{c}\text { plantation ( } 765 \\
\text { hybrid) }\end{array} \\
\text { (Winter plantation) }\end{array}$} & \multirow{2}{*}{ Leaves } & Temp $p_{\text {average }}$ & $0.69 * *$ & $71.7 \%$ & $21.1^{* *}$ \\
\hline & & R.H. $\%_{\text {average }}$ & -0.36 & - & -3.36 \\
\hline & \multirow{2}{*}{ Fruits } & Temp $p_{\text {average }}$ & $0.63^{*}$ & $63.2 \%$ & $5.42 *$ \\
\hline & & R.H. $\%_{\text {average }}$ & -0.16 & - & 0.24 \\
\hline \multirow{4}{*}{$\begin{array}{c}\mathbf{3}^{\text {rd }} \text { plantation (Super } \\
\text { Jakal) } \\
\text { (Summer plantation) }\end{array}$} & \multirow{2}{*}{ Leaves } & Temp $p_{\text {average }}$ & -0.42 & $53.9 \%$ & -20.48 \\
\hline & & R.H. $\%_{\text {average }}$ & -0.44 & & -4.77 \\
\hline & \multirow{2}{*}{ Fruits } & Temp $p_{\text {average }}$ & - & & \\
\hline & & R.H. $\%_{\text {average }}$ & - & & \\
\hline \multirow{4}{*}{$\begin{array}{c}4^{\text {th }} \text { plantation ( } 765 \\
\text { hybrid) }\end{array}$} & \multirow[t]{2}{*}{ Leaves } & Temp average & $\begin{array}{c}- \\
0.55^{* *} \\
\end{array}$ & $56.6 \%$ & $\begin{array}{c}- \\
18.4^{* *} \\
\end{array}$ \\
\hline & & R.H.\% $\%_{\text {average }}$ & 0.23 & & 9.18 \\
\hline & \multirow{2}{*}{ Fruits } & Temp $p_{\text {average }}$ & -0.16 & $38.5 \%$ & $-4.06^{*}$ \\
\hline & & R.H. $\%_{\text {average }}$ & 0.023 & & -1.7 \\
\hline
\end{tabular}

Fayoum J. Agric. Res. \& Dev., Vol. 28, No.1, January, 2014 
Abd - El-Gayed, A. A., et al.,

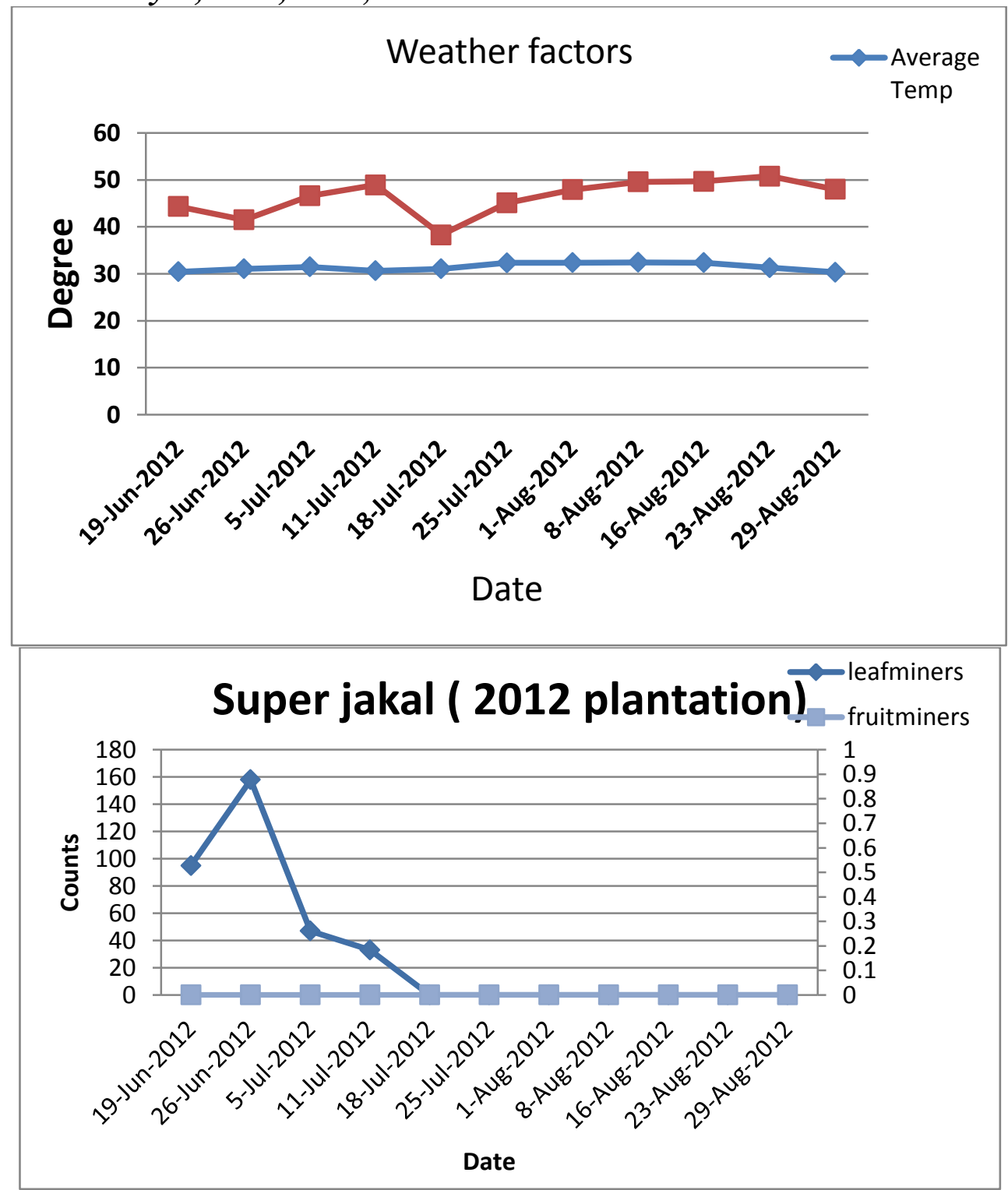

Fig. (1): Weekly counts of larvae/20 leaves and 20 fruits on tomato plants at Fayoum in summer plantation 2012.

Fayoum J. Agric. Res. \& Dev., Vol. 28, No.1, January, 2014 
POPULATION DYNAMICS OF TOMATO PIN WORM

\subsection{Winter plantation}

\subsubsection{Winter plantations (2011/12):}

Data illustrated in (Fig. 2) represent the weekly counts of the calculated larvae/20 compound leaves and fruits of tomato plants cultivated in winter season, 2011/12 during the period from November 2011 to May 2012. Fluctuations of such data in relation to some weather factors indicated total counts of 28 larvae at the end of Nov. 2011 at $18.78^{\circ} \mathrm{C}$ and $54.18 \%$ R.H.

In subsequent weeks, population fluctuated where the highest count (410 larvae / 20 compound leaves) was in mid-April (Fig. 2) at $21^{\circ} \mathrm{C}$ and 47.71. $\%$ R.H. Thereafter, reductions larvae occurred during the successive two weeks of April, while in May, no larvae were observed.

On other hand, fruit infestation appeared at the end of April and extended to the end of plantation, fluctuated between 34-79 larvae / 20 fruits at temperature ranged between 21.4 and $27.4^{\circ} \mathrm{C}$ and R.H\% ranged from 42.86 to $03.14 \%$ R.H.

Data in Fig (2) indicated that the population of $T$. absoluta fluctuated slightly during most of the season from 21 Nov. 2011 until end of Feb, and began to increase obviously towards the end of the season to record one activity period from end of Feb. to the end of April, at temp. fluctuated between 15.9$19.8^{\circ} \mathrm{C}$ and $46.6-56.1 \%$ R.H.

Statistical analyses ; simple correlation (r) and regression (b) coefficients, indicated positive and highly significant for temp average for each leaves and fruits larvae coincided with the $b$ values of temp average $21.1^{* *}$ and $5.42 *$, while, effect of R.H.\% was insignificant for count of larvae recorded on leaves and fruits. However, the value of R.H. was $71.7 \%$ for leaves larvae and $63.2 \%$ for fruits larvae

\subsubsection{Winter plantation (2012 /2013):}

As shown in Fig (3), this plantation was transplanted during the last week of August 2012 and no larvae were observed on leaves until the first week of Nov. 2012, where temp. fluctuated between 26.76 and $29.61^{\circ} \mathrm{C}$ with 46.43 and $52.05 \%$ R.H. Also for fruits, no infestation was observed until mid of Dec. at 14.33 - 29.54 ${ }^{\circ} \mathrm{C}$ with 44.79 and 52\% R.H. During the successive weeks, for larvae on leaves, they began at a lowest count (7 larvae/20 compound leaves) in mid of Nov. 2012 at $23.64{ }^{\circ} \mathrm{C}$ and $47.10 \%$ R.H., increased gradually during the successive winter months to reach the highest peak (618 larvae/20 leaves) at the end of Feb. 2013.

One period of activity extended from early Dec 2012 until the end of the season.

Fayoum J. Agric. Res. \& Dev., Vol. 28, No.1, January, 2014 

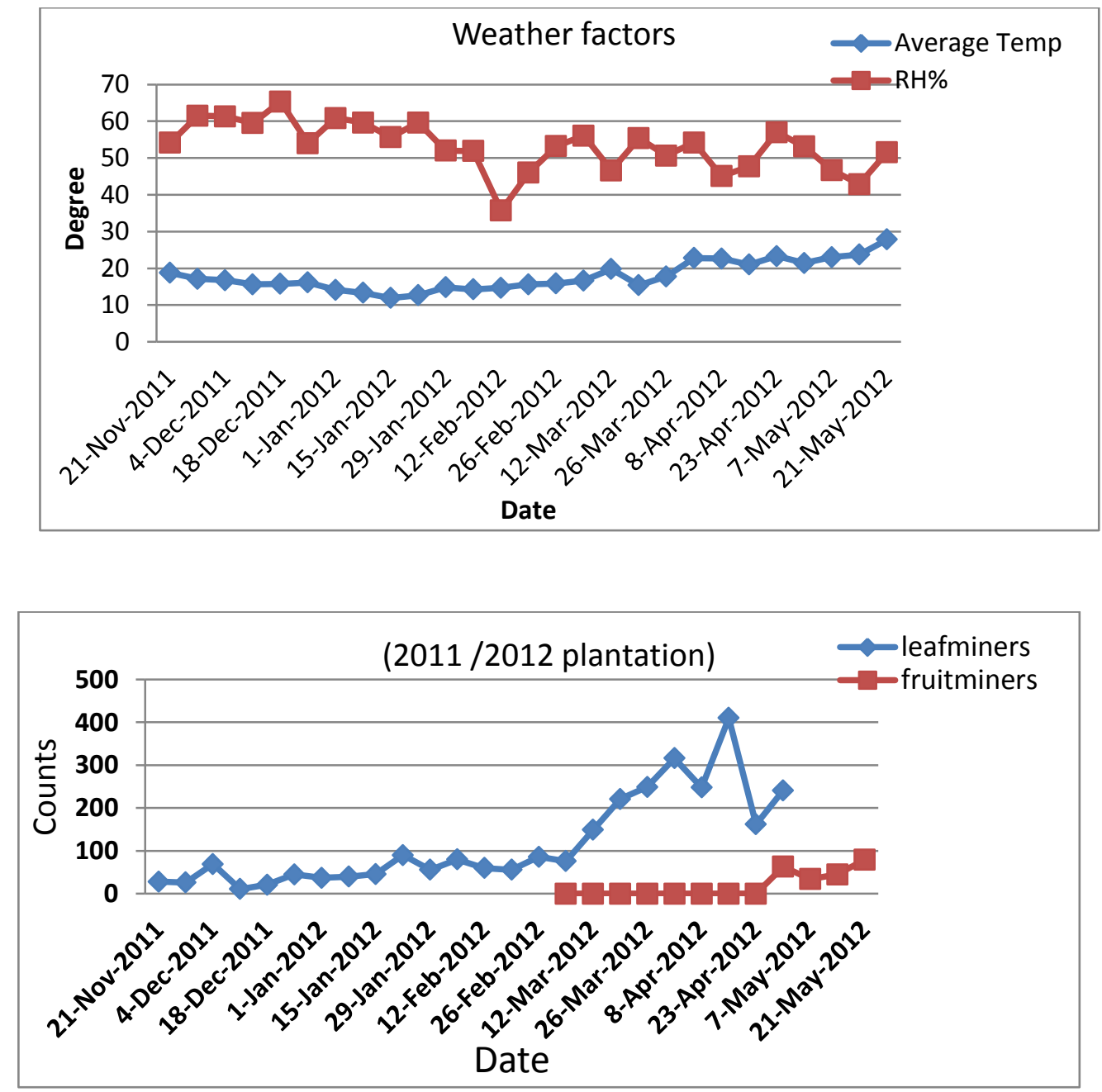

Fig.(2): Weekly counts of larvae/20 compound leaves and fruits on tomato plants in Fayoum Governorate in winter plantation (2011/12).

For fruits infestation, the lowest (4 Larvae/20 compound fruits) was recorded during the last week of Dec.2012 at $13.36{ }^{\circ} \mathrm{C}$ and $49 \%$ R.H, increased to the highest (214 larvae/20 fruits) in the first week of March 2013 at $20.6{ }^{\circ} \mathrm{C}$ and $45.9 \%$ R.H.

A slight period of activity was observed during the period extended from mid-January until the end of Feb. 2013 (Fig. 3).

Statistical analyses showed negatively and significant relation with pest population on leaves and fruits, while the effect of R.H \% was positive and insignificant.

Fayoum J. Agric. Res. \& Dev., Vol. 28, No.1, January, 2014 
POPULATION DYNAMICS OF TOMATO PIN WORM

In this respect, Nannini et al. (2012) in Southern Sardinia (Italy) observed the highest numbers of moths caught in traps between April and June and in September-October. Similarly, the highest levels of tomato borer infestation were observed in spring and, to a lesser extent, in Autumn, while in spring T. absoluta frequently reached maximum densities of 40-100 larvae/plant, during Autumn, its densities did not exceed 25 larvae/plant.
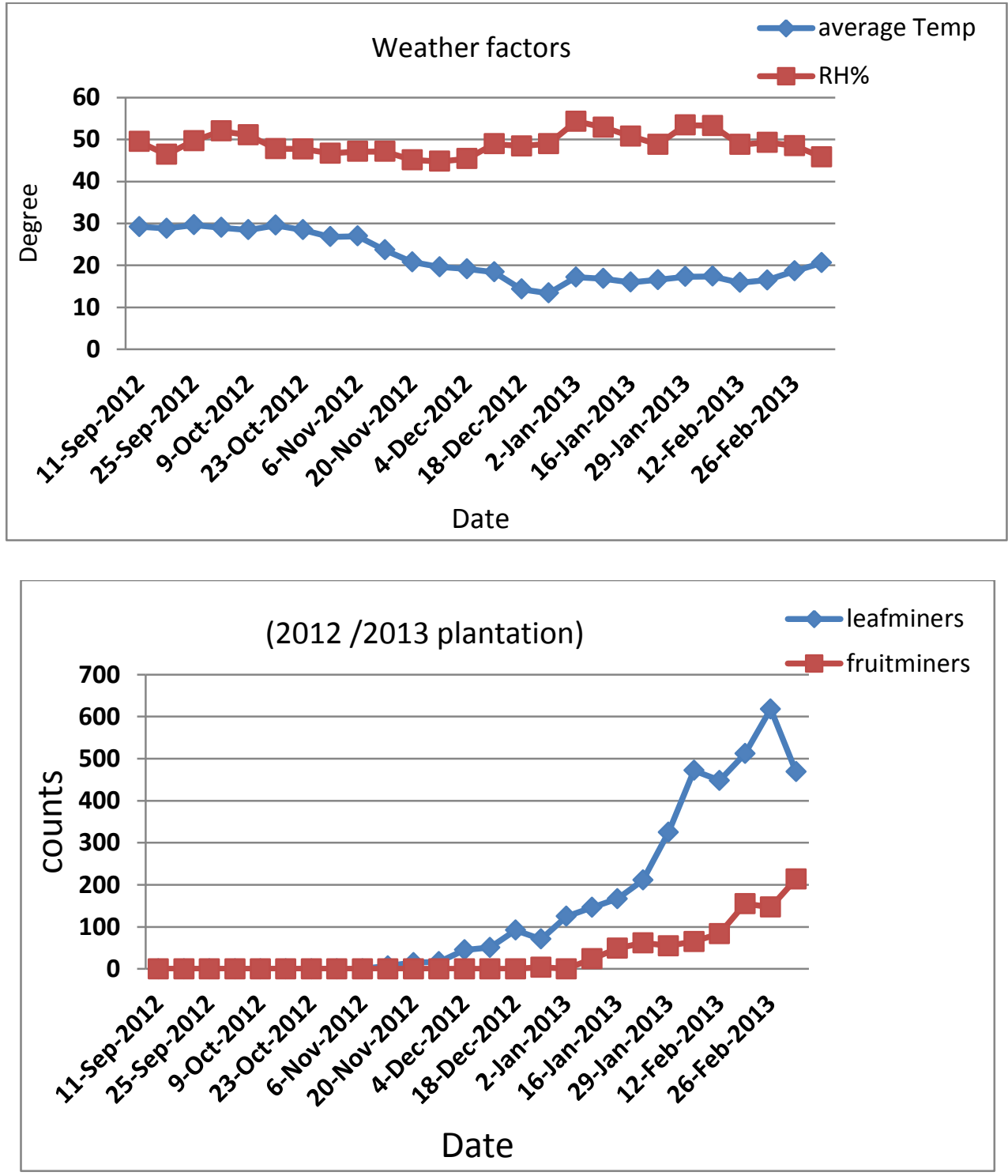

Fig.(3): Weekly counts of larvae / 20 compound leaves and fruits tomato plants at Fayoum Governorate in winter plantation (2012/13).

Fayoum J. Agric. Res. \& Dev., Vol. 28, No.1, January, 2014 
REFERENCES

Alberto, U.; Joel G. C.; Judit, A. and Rosa, G. (2012): Prospects for the biological control of Tuta absoluta in tomatoes of the Mediterranean basin. Pest. Manag. Sci.,68:1215-1222.

Bekheit, H. K. M and Impiglia, A., (2011): Tuta absoluta (tomato borer) outbreak and control measures in Egypt. EPPO/IOBC/FAO/NEPPO Joint International Symposium on management of Tuta absoluta (tomato borer) Agadir, Morocco, November 16-18,69.

Lucia, Z.; Umberto, B.; Antonio, B.; Arturo, C.; Salvatore, D.; Gavino, D.; Massimo, G.; Paolo, P.; Carmelo, R.; Giovanna, T. G. and Gaetano, S. (2012): Recruitment of native parasitoids by the exotic pest Tuta absoluta in Southern Italy. Bull insectology Filograf Litografia.,65(1):51-61.

Mack, R.; Barrett, S.; de Fur, P.; MacDonald, W.; Madden, L.; Marshall, D.; McCullough, D.; McEvoy, P.; Nyrop, J.;Reichard, S.; Rice, K. and Tolin, S. (2002): Predicting invasions of nonindigenous plants and plant pests. National Academy of Sciences, Washington, DC

Marchiori, C. H.; Silva, C. G. And Lobo, A. P. (2004): Parasitoids of Tuta Absoluta Meyrick, 1917 (Lepidoptera: Gelechiidae) Collected on Tomato Plants In Lavras, State of Minas Gerais, Brazil. Brazilian. J. Biology.,64(3a):551-552.

Massimo, G.; Umberto, B. and Paolo, A. P. (2012): The parasitoid complex of Tuta absoluta (Meyrick) in Italy. Atti Accademia Nazionale Italiana di Entomologia Anno LX:77-84.

Melo, M. and Campos, A. D. (2000): Occurrence of natural enemies on tomato moth, Tuta absoluta Meirick (Lepidoptera: Gelechiidae) in Pelotas, Rio Grande do Sul. Agropecuaria Clima Temperado.,ㅆ⑵:269274.

Moacyr, M. M. M.; Marcelo, C. P.; José, C. Z.; Leandro, B. and silva, E. M. D. (2005): Impact of integrated pest management on the population of leaf miners, fruit borers, and natural enemies in tomato. Ciência Rural, Santa Maria., 35(1):204-208.

Probst, K.; Pulschen, L.; Sauerborn, J. and Zebitz, C. P. W. (1999): Influence of several pesticide use regimes on the entomofauna of tomato on highlands in Ecuador. Manejo Integrado de Plagas., (54):53-62.

Nannini, M.; Atzori, F.; Foddi, F.; Pisci, R. and Sanna, F. (2010): A Survey of Tuta absoluta Meyrick (Lepidoptera: Gelechiidae) Outbreaks in Tomato Greenhouses in Southern Sardinia (Italy). Thematic Sessions T10 Integrated Pest Management T10.009.,:214-215.

Saad, M.; Anil, S.; Fatina, B. and Fathi, E. E. A. (2013): The Status of Tomato Leaf miner; Tuta absoluta Meyrick (Lepidoptera: Gelechiidae)

Fayoum J. Agric. Res. \& Dev., Vol. 28, No.1, January, 2014 
POPULATION DYNAMICS OF TOMATO PIN WORM

in Egypt and Potential Effective Pesticides. Academic. J. Entomol.,6(3):110-115.

Senedecor, G. W. and Cochran, W. G. (1967): Statistical methods. The Iowa State, Univ. Press. Ames. Jowa, USA, $6^{\text {th }}$ ed.

Sobhy, A. T. (2011): The status of Tuta absoluta in Egypt. $\mathrm{EPPO} / \mathrm{IOBC} / \mathrm{FAO} / \mathrm{NEPPO}$ Joint International Symposium on management of Tuta absoluta (tomato borer) Agadir, Morocco, November 16-18.,18.

\section{تذبذب تعداد حشرة Tuta absoluta ( حرشفية الأجنحة - جيليثيدي ) وحصر لاعدائها الطبيعية على الطماطم فى محافظة الفيوم

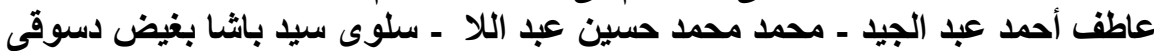 قسم وقاية النبات ـ كلية الزراعة - جامعة الفيوم}

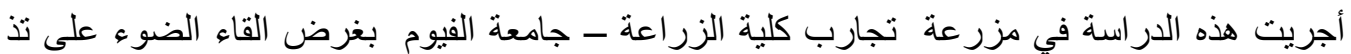

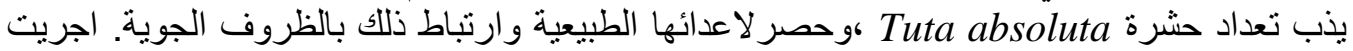

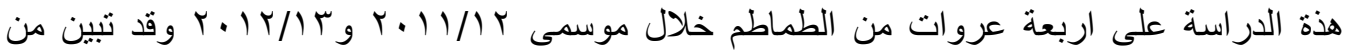
البحث ان من اهم المفرسات المرتبطة بهذة الافة المفترس الحشرى .Atheta sp التايع لرئ لرنبة غمدية

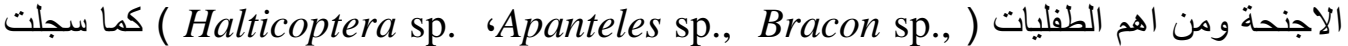

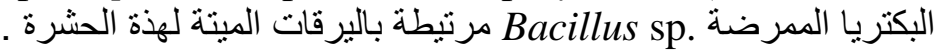

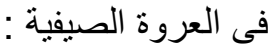

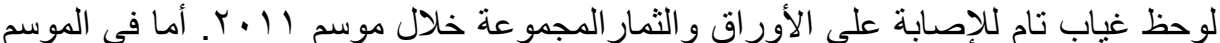

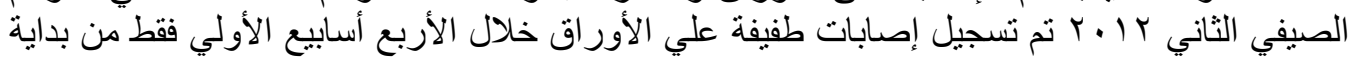

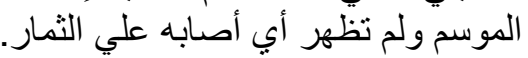

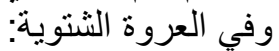

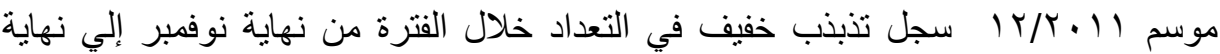

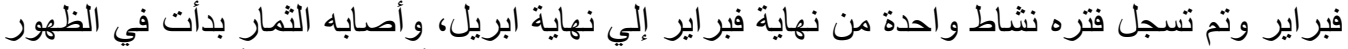

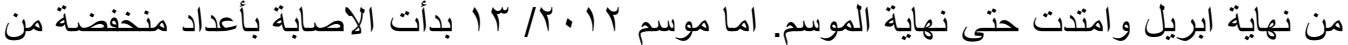

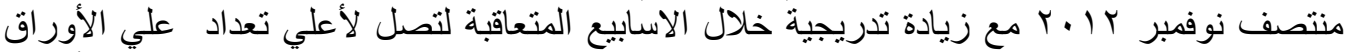

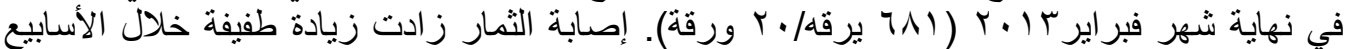

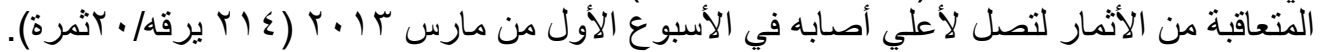

